ДВНЗ «Київський національний економічний університет імені Вадима Гетьмана»

\title{
МЕТОДИЧНИЙ ІНСТРУМЕНТАРІЙ ТА ПРИКЛАДНІ АСПЕКТИ ОЦІНЮВАННЯ НЕСТАБІЛЬНОСТІ ЗОВНІШНЬОГО СЕРЕДОВИЩА ВИНОРОБНИХ ПІДПРИЕМСТВ УКРАЇНИ
}

\author{
МЕТОДИЧЕСКИЙ ИНСТРУМЕНТАРИЙ И ПРИКЛАДНЫЕ АСПЕКТЫ \\ ОЦЕНИВАНИЯ НЕСТАБИЛЬНОСТИ ВНЕШНЕЙ СРЕДЫ ВИНОДЕЛЬЧЕСКИХ \\ ПРЕДПРИЯТИЙ УКРАИНЫ
}

\section{METHODOLOGICAL TOOLS AND PRACTICAL ASPECTS INSTABILITY OF THE ENVIRONMENTAL ASSESSMENT WINERIES UKRAINE}

Розглянуто дискусійні положення теорії нестабільності зовнішнього організаційного середовища, обтрунтовано оціночні критерії рівня нестабільності, щуо трунтуються на наявності тендениії у динаміці досліджуваних показників, диференційованої варіативності та спонтанності їх змін. Запропоновано типізацію зовнішнього організаційного середовища за ознаками динамічності,турбулентності, стахостичності та стагнації. Сформовано систему показників та розроблено методичний інструментарій оцінювання рівня нестабільності зовнішнього організачійного середовища на основі матричного позиціонування диференційованих параметрів показників нестабільності. Здійснено вибір показників об'єктів очінки рівня нестабільності середовища діяльності виноробних підприємств Украӥни, шьо трунтувався на вимогах системності, функціональної незалежності, кількісної вимірності і зосередженість на основних галузевих характеристиках. Проведено розрахунки нестабільності досліджуваного середовища за 2007 - 2013 рр., визначено ї̈ пріоритетний характер та рівень диференціації по окремих сегментах діяльності. Сформовано аналітичні висновки, що відображають стан, динаміку та прогнозні характеристики трансформації досліджуваної галузі.

Ключові слова: зовнішнє середовище, фактори нестабільності, показники нестабільності, виноробні підприємства.

Рассмотрены дискуссионные положения теории нестабильности внешней организационной среды, обоснованно оценочные критерии уровня нестабильности, основанные на наличии тенденции в динамике исследуемых показателей, дифференцированной вариативности и спонтанности их изменений. Предложено типизацию внешнего организационной среды по признакам динамичности, турбулентности, стахостичности $u$ стагнации. Сформирована система показателей и разработан методический инструментарий оценки уровня нестабильности внешней организационной среды на основе матричного позиционирования дифференцированных параметров показателей нестабильности. Осуществлен выбор показателей - объектов оценки уровня нестабильности среды деятельности винодельческих предприятий Украины, основанного на требованиях системности, функииональной независимости, количественной измеримости $u$ сосредоточенность на основных отраслевых характеристиках. Проведены расчеты нестабильности исследуемой среды за 2007 - 2013 г2. Определены ее приоритетный характер и уровень дифференцииации по отдельным сегментам деятельности. Сформирован аналитические выводы, отражающие состояние, динамику и прогнозные характеристики трансформации исследуемой области.

Ключевые слова: внешняя среда, факторы нестабильности, показатели нестабильности, винодельческие предприятия. 
The argumentative ideas of the Theory of instability of external organizational environment are considered, the evaluation criteria of instability level are explained based on tendency in the dynamics of the studied parameters, differentiated variability and spontaneity of their changes. The typing of external organizational environment is proposed based on signs of dynamism, turbulence, stochastic and stagnation. The system of indicators and the methodological tools of evaluation the level of instability of external organizational environment are developed based on matrix positioning of instability differential indexes. The choice of indicators - objects of the assessment of environmental instability of Ukrainian wineries is defined, it is based on the requirements of the systematic, functional independence, quantitative evaluation and focus on key industry characteristics. The calculation of key indicators of instability of researched environment in 2007 2013 is done and defined its priority nature and base of differentiation for individual business segments. The analysis results are collected, they demonstrate the state, dynamics and predictive characteristics of transformation of the study area.

Key words: external environment, instability factors, instability indexes, wineries.

Вступ. Сучасні трансформації в сфері діяльності суб'єктів ринку нерозривно пов'язані із змінами зовнішнього організаційного середовища. Підприємства, як відкриті системи, відчувають на собі зростаючий вплив зовнішніх чинників, динаміка яких має здебільшого непередбачуваний характер. Але знання характеру і рівня нестабільності середовища необхідні менеджменту підприємств для формування ефективних стратегічних рішень і визначення поточних управлінських дій задля попереджуючих рішень 3 метою нівелювання негативних і використання позитивних зовнішніх зрушень.

Проблема нестабільності зовнішнього організаційного середовища давно привернула увагу науковців. Вагомі дослідження характеру ринкового середовища належать відомим американським і європейським вченим Ф. Емері, Е. Трісту, I. Ансоффу, Р. Дункану. 3 прикладних позицій до вирішення даної проблеми долучились українські вчені Н.В. Васюткін, Д.В. Кіпа, Г.О. Копосов, В.С. Момот, А.А. Мазаракі, Д.М. Пшеслінський, І.В. Смолін, П.Г. Шелухін та інші. Предметом їхньої уваги стали якісні характеристики та чинники нестабільності середовища, взаємозв'язок зовнішнього середовища і діяльності суб'єктів ринку. Вирішення завдання визначення рівня нестабільності середовища більшістю вчених вирішувалась у форматі експертних оцінок, або кількісної оцінки впливу макрофакторів на діяльність окремих підприємств.

Разом 3 цим, зовнішнє організаційне середовище в окремих галузях економіки має диференційований рівень нестабільності, визначення якого потребує розробки відповідного інструментарію оцінки, основаного на врахуванні об'єктивних ознак.

Особливо актуальним є визначення рівня нестабільності середовища у галузях, які відчувають його зростаючий негативний вплив. Так, виноробні підприємства України перебувають під посиленим впливом на лише загальнонаціональних соціально-економічних i політичних умов діяльності. Виробляючи продукцію високого еластичного рівня, вони стикаються 3 непередбачуваною динамікою попиту, яка залежить від рівня доходу споживачів, активності товарів-замінників, інтенсивності конкуренції у сфері експортноімпортних поставок, тощо. Комплексне оцінювання параметрів нестабільності 
такого середовища $\epsilon$ неодмінною передумовою ефективної управлінської діяльності, як на галузевому, так і корпоративному рівнях.

Постановка завдання. Актуальність проблеми визначення характеру зовнішнього організаційного середовища обумовлює необхідність: вибору об'єктів оцінювання, динаміка параметрів яких слугуватиме аналітичною базою для формування висновків щодо рівня нестабільності досліджуваного середовища; розроблення методики розрахунку комплексу показників нестабільності; перевірки дієвості визначеного інструментарію, зокрема в сфері діяльності виноробних підприємств України.

Методологія дослідження. При формуванні теоретичних підходів до визначення об'єктів оцінювання нестабільності організаційного середовища використовувались методи наукового узагальнення, абстракції, аналогії та синтезу. Методичні i прикладні аспекти оцінки i аналізу параметрів нестабільності організаційного середовища діяльності виноробних підприємств грунтувались на методах статистичного i математичного аналізу, ретроспективного моделювання, матричного позиціонування. Їхнє комплексне застосування слугувало науковою базою отриманих висновків і пропозицій.

Результати дослідження. Одними 3 перших дослідників невизначеності організаційного середовища були Ф. Емері i Е. Тріст, які опублікували фундаментальні роботи 3 теорії динамізму зовнішнього середовища "Невизначенність побудови організаційного середовища" (1965) [8] і "До питання про соціальну екологію" (1973) [9]. Вони визначили наступні типи зовнішнього середовища організації:

- спокійне зовнішнє середовище, що не потребує помітних змін у діяльності організації;

- спокійне, але сконцентроване середовище, яке потребує зосередженості організації на ідентифікації змін і визначенні адекватних стратегічних дій;

- динамічне, сконцентроване середовище, в якому діяльність організації має досліджувати конкурентні зусилля суперників і діяти на випередження, що потребує точної і швидкої реакції;

- турбулентне середовище, яке відрізняється складністю чисельних взаємозв'язків, які не піддаються прогнозуванню.

Заслуговує на увагу структурований підхід до ідентифікації характеру зовнішнього середовища, запропонований Р. Дунканом [7, с. 45].

Його двомірна модель включає дві змістовні складові середовища - ступінь чисельності та подібності факторів зовнішнього середовища. Для "простого" середовища характерна невелика кількість подібних факторів нестабільності, для "складного" - багато різноманітних факторів. Матричне поєднання даних характеристик дозволяє сформувати можливі варіанти їх взаємодії (табл. 1).

Таблиця 1

Оцінювання зовнішнього середовища за двомірною моделлю Р. Дункана 


\begin{tabular}{|c|c|c|}
\hline Статичне & $\begin{array}{l}\text { Низька невизначеність: } \\
-\quad \text { невелика кількість факторів і } \\
\text { компонентів; } \\
-\quad \text { фактори і компоненти подібні } \\
\text { один до одного; } \\
\text { - фактори і компоненти } \\
\text { фактично незмінні. } \\
\text { Приклад: напої промислового } \\
\text { виробництва. }\end{array}$ & \begin{tabular}{|} 
Помірно низька \\
невизначеність: \\
-велика кількість факторів \\
і компонентів; \\
-фактори і компоненти не \\
схожі один на одного; \\
- фактори і компоненти \\
практично не змінюються. \\
Приклад: харчова \\
промисловість.
\end{tabular} \\
\hline Динамічне & $\begin{array}{c}\text { Помірно висока невизначеність: } \\
\text { - невелика кількість } \\
\text { факторів і компонентів; } \\
\text { - фактори і компоненти } \\
\text { подібні один до одного; } \\
\text { - фактори і компоненти } \\
\text { знаходяться в процесі } \\
\text { змін. }\end{array}$ & $\begin{array}{l}\text { Висока невизначеність: } \\
\text {-невелика кількість } \\
\text { факторів і компонентів; } \\
\text {-фактори і компоненти не } \\
\text { схожі один на одного; } \\
\text {-фактори і компоненти } \\
\text { знаходяться в процесі } \\
\text { безперервних змін. }\end{array}$ \\
\hline & $\begin{array}{l}\text { Приклад: індустрія швидкого } \\
\text { харчування. }\end{array}$ & $\begin{array}{l}\text { Приклад: телекомунікації, } \\
\text { комерційні авіаперевезення. }\end{array}$ \\
\hline
\end{tabular}

За даною моделлю, на думку автора, можна визначити характер зовнішнього організаційного з урахуванням ступеня складності продукту, що виробляє організація. 3 цього випливає важливий висновок щодо того, що не існує рівня невизначеності середовища поза сферою виробництва і реалізації конкретного продукту. Рівень невизначеності середовища має конкретизовані характеристики відносно сфери діяльності підприємства, або навіть окремих його продуктів.

Розглянуті підходи до визначення типів середовища і їхніх характеристик мають виключно якісні ознаки, які дозволяють ідентифікувати характер оточуючого середовища на основі експертної оцінки, яка як відомо, має значний рівень суб'єктивізму.

Спробу вирішення цієї складної проблеми здійснив I. Ансофф [1, с. 402]. Він запропонував три групи методів визначення майбутніх змін, що відповідають певному рівню динамізму зовнішнього середовища, зокрема, прогнозування, моделювання та експертне оцінювання. Цим вчений вказував на можливість диференційованого підходу до оцінки та аналізу рівня динамізму зовнішнього середовища на основі різних методичних підходів.

Сучасні вітчизняні вчені зосередили свою увагу на визначенні структури зовнішнього середовища за рівнями його агрегації. Так, Д.В. Кіпа дослідив характер впливу організаційного середовища на формування конкурентної стратегії підприємства [3, с. 189 - 193]. Здійснена якісна оцінка мала б більш вагомий прикладний результат за умови кількісного визначення рівна зазначеного впливу.

А.А. Мазаракі, Д.М. Пшеслінський i I.В. Смолін запропонували диференціація нестабільності середовища за критеріями варіативності, 
динамічності i флуентності [5, с. 82]. Зазначимо, що ідентифікація типів середовища за даними критеріями є суб'єктивною, а кількісне оцінювання нестабільності потребує визначення ключових показників динаміки і способів їх вимірювання.

Значна частина дослідників, використовує поняття невизначеності, нестабільності як характеристики, які не потребують змістовного вивчення i, тим більше, кількісного оцінювання [4, с. 195 - 198] , [2, с. 384 - 389]. Разом $з$ цим, рівень невизначеності, у кожному конкретному випадку, має диференційовані ознаки.

Необхідною передумовою вирішенням такої складної проблеми як оцінка рівня нестабільності зовнішнього середовища $є$ з'ясування відповідних оціночних критеріїв. Основними критеріями, як мірила рівня нестабільності середовища, можуть бути:

1. Критерій наявності тенденції у зміні досліджуваних показників, що $є$ свідченням можливості прогнозування зазначених показників та відповідності ознаці динамічного детермінованого середовища.

2. Критерій варіативності змін дає можливість диференціювати рівень нестабільності середовища за відсутності тенденції його динаміки. На основі оцінки параметрів відхилення досліджуваних показників від їх середньої величини виявляються амплітудні ознаки коливань, що слугують основою 3'ясування характеру стохастичності досліджуваного середовища.

3. Критерій спонтанності потужних змін слугує мірилом їх щільності за визначений період. Кількість зазначених змін зазвичай є невеликою, але їхня значимість дає підстави кваліфікувати середовище як нестабільне $з$ елементами стохастичності при збереженні певної тенденції динаміки досліджуваного показника.

4. Критерій періодичної диференціації варіативності змін визначає наявність аритмії у варіації відхилень у часі, що $є$ свідченням ненадійності виявленої тенденції, а отже і значної нестабільності середовища.

На основі даних критеріїв формується уявлення про відповідний тип зовнішнього організаційного середовища:

- динамічне середовище, в якому відбуваються трансформації, що мають ознаки тренду 3 незначними відхиленнями та диференційованою інтенсивністю;

- турбулентне середовище, 3 характерними для нього періодичним прискоренням змін, які провокують хаотичні відхилення в значному інтервалі;

- стагнаційне середовище характеризується застійними явищами, що виявляються у близьких до нуля темпами динаміки і відсутністю близьких перспектив зростання;

- стохастичне середовище відрізняється випадковими безладними змінами, які $\epsilon$ результатом дії невизначених факторів, що мають різноспрямований вектор. Зазначене унеможливлює існування фіксованого тренду показників середовища. 
Таким чином, диференціація типів зовнішнього організаційного середовища пов'язана 3 ідентифікацією тенденцій динаміки показників, що визначають його характер.

3 огляду на запропоновані критерії можна виокремити наступні показники оцінки, що дозволять ідентифікувати тип зовнішнього організаційного середовища.

1. Коефіцієнт часової кореляції за визначеним трендом (r). За значимої кореляції $(\mathrm{r} \geq 0,75)$ динаміка досліджуваного показника має чітку тенденцію, що передбачає можливість здійснення прогнозних розрахунків. Дані характеристики свідчать про не стохастичний характер середовища за даним показником.

2. Коефіцієнт варіації у часі (Кв):

$$
K B=\frac{\sqrt{\sum(\Pi \mathrm{t}-\Pi c)^{2}} / t}{\Pi c}
$$

де: П $t$ - значення показниках по роках досліджуваного періоду;

Пс - середнє значення показника;

$t$ - кількість років досліджуваного періоду.

Даний коефіцієнт застосовується за умови відсутності тенденції динаміки досліджуваного показника. Але вона може бути зафіксована як за відносної незмінності даного показника у часі, так і за значних його хаотичних відхилень. Останнє і фіксується за допомогою даного показника. Відсутність тенденції динаміки за низьких значень Кв є ознакою стагнаційного середовища, за високих значень - стохастичного.

Критерій якісних ознак даного коефіцієнта (високий/низький) визначається суб'єктом оцінки в залежності від особливостей досліджуваного середовища. За усереднених підходів високе значення коефіцієнта варіації показника нестабільності середовища має бути більшим за 0,30 .

3. Коефіцієнт прискорення(Кп):

$$
\mathrm{K} \Pi=\sqrt[n]{\mathrm{I}_{1} * \mathrm{I}_{2} \ldots \mathrm{I}_{\mathrm{n}}}
$$

Де: I1, I2, In - ланцюгові індекси прискорення досліджуваного показника (ланцюгові індекси з ланцюгових індексів);

$\mathrm{n}$ - кількість ланцюгових індексів прискорення.

Умовою застосування даного коефіцієнта $є$ наявність зростаючої тенденції досліджуваного показника. Свідченням прискорення його динаміки є наступна умова:

$$
\text { Кп }>1 .
$$

Прискорена динаміка передує турбулентним змінам середовища, що робить прогностичні розрахунки умовними.

4. Коефіцієнт щільності пікових відхилень(Кщ): 


$$
\text { Кщ }=\frac{\sum \Delta \Pi \Pi}{\mathrm{t}}
$$

де: $\sum п \Delta П$ - кількість пікових відхилень досліджуваного показника за період $t$.

Відхиленням визначається різницю між наступним i попереднім значеннями досліджуваного показника. Відхилення слід вважати піковим за умови:

$$
\Delta \Pi / \sigma>1,
$$

Де: $\sigma$ - середньо квадратичне відхилення досліджуваного показника від теоретичних значень лінії тренду, або за відсутності тенденції - від середнього значення за період спостереження.

Коефіцієнт щільності пікових відхилень диференціюється за наступними його значеннями:

$$
\begin{gathered}
0<\text { Кщ }<0,25 \text { - низьке значення; } \\
0,26<\text { Кщ - високе значення. }
\end{gathered}
$$

Зазначена диференціація обумовлена наступними обставинами:

- кількість пікових відхилень не може дорівнювати і перевищувати 50\% загальної кількості досліджуваних відхилень. В іншому випадку значення середньоквадратичного відхилення їх поглине і зазначені відхилення не будуть відповідати вимозі $\Delta \Pi / \sigma>1$;

- за умови диференціації показника за двома якісними рівнями, рівний розподіл визначеної амплітуди вбачається виправданим.

5. Коефіцієнт аритмії (Ка):

$$
\mathrm{Ka}=\sigma=\sqrt{\frac{\sum\left(\mathrm{K}_{\mathrm{t}}-\mathrm{K}_{\mathrm{B}}\right)^{2}}{\mathrm{n}}}
$$

Де: Кв ${ }_{t}-$ коефіцієнт варіації за $\mathrm{t}$ період;

Кв -значення коефіцієнта варіації за увесь час спостереження;

$\mathrm{n}$ - кількість періодів спостереження.

Значимість Ка задається на основі експертного підходу. При Ка > 0,3 значима аритмія буде визнана при 30\% відхиленні коефіцієнтів варіації по окремих періодах від значення даного показника за увесь час спостереження. Експертне визначення $K a$ залежить від об'єктивної особливості динаміки досліджуваного показника. Так, показники фінансового стану, рентабельності мають більший потенціал варіації у порівняння з показниками обсягу діяльності підприємств, чисельності працюючих тощо.

Призначенням цього коефіцієнту є визначення рівня диференціації варіації досліджуваного показника у часі. Його застосування передбачає наявність ретроспективи мінімум за два окремі періоди ( чотири точки спостереження). 
Оцінка рівня нестабільності зовнішнього організаційного середовища здійснюється на основі запропонованих коефіцієнтів, розрахованих за параметрами показників досліджуваного ринку, і узагальнених за допомогою методу матричного позиціонування (табл. 2).

Неможливі варіанти конфігурації коефіцієнтів нестабільності організаційного середовища (х) обумовлені недоречністю, або алогічністю поєднання окремих ознак. Зокрема:

- за високої трендової кореляції $\left(\mathrm{r}^{\mathrm{B}}\right)$ розрахунок варіації досліджуваного показника (v) $\epsilon$ недоречним, оскільки він відображає подібну характеристику середовища. Алогічним $є$ поєднання високої трендової кореляції з високими значеннями коефіцієнтів щільності пікових відхилень (Кщ) і аритмії (Ка), які суперечать першій ознаці;

- за низької трендової кореляції $\left(\mathrm{r}^{\mathrm{H}}\right)$ високе значення прискореної динаміки неможливе 3 причини відсутності тенденції у динаміці досліджуваного показника.

Слід також зазначити, що конфігурації значень показників нестабільності у деяких випадках мають обмежений склад 3 причини недоречності подальшої диференціації, але представляють аналітичну цінність і потребують відповідної інтерпретації. Зокрема, варіанти $\mathbf{r}^{\mathbf{B}} \mathbf{K} \mathbf{\Pi}^{\mathbf{B}} \mathbf{i} \mathbf{r}^{\mathbf{B}} \mathbf{K}^{\mathbf{H}}$ не потребували доповнення характеристиками варіації, яка не могла бути значимою 3 причини високої трендової кореляції досліджуваного показника. Але поєднання ознак, що містять зазначені конфігурації, мають значиме змістовне наповнення, яке посилить обгрунтованість висновків, особливо щодо перспектив зміни динаміки даного показника. Так, за високих значень коефіцієнта прискорення при значимій трендовій кореляції $\left(\mathbf{r}^{\mathbf{B}} \mathbf{K}^{\mathbf{B}}\right)$ можна припустити, що у перспективі досліджуваний показник може потрапити до зони турбулентності. Ймовірно, що цього не станеться за відсутності прискорюючих динаміку даного показника ознак $\left(\mathbf{r}^{\mathbf{B}} \mathbf{K} \mathbf{I}^{\mathbf{H}}\right)$.

Таблиця 2

Конфігурація значень коефіцієнтів нестабільності організаційного середовища підприємства* .

\begin{tabular}{|c|c|c|c|c|}
\hline $\begin{array}{l}\text { Коефіцієнт } \\
\text { кореляції, r }\end{array}$ & $\begin{array}{l}\text { Коефіціснт } \\
\text { варіації, } \\
\text { v }\end{array}$ & $\begin{array}{c}\text { Коефіцієнт } \\
\text { прискорення, Кп }\end{array}$ & $\begin{array}{c}\text { Коефіцієнт щільності } \\
\text { пікових відхилень, } \\
\text { Кщ }\end{array}$ & Коефіцієнт аритмій, Ка \\
\hline \multirow{14}{*}{$\mathrm{r}^{\mathrm{B}}$} & \multirow{8}{*}{$r^{\mathrm{B}} v^{\mathrm{B} * *}$} & \multirow{4}{*}{$\mathrm{x}$} & \multirow[t]{2}{*}{$\mathrm{x}$} & $\mathrm{x}$ \\
\hline & & & & $\mathrm{x}$ \\
\hline & & & \multirow[t]{2}{*}{$\mathrm{x}$} & $\mathrm{x}$ \\
\hline & & & & $\mathrm{x}$ \\
\hline & & \multirow{4}{*}{$\mathrm{x}$} & \multirow[t]{2}{*}{$\mathrm{x}$} & $\mathrm{x}$ \\
\hline & & & & $\mathrm{x}$ \\
\hline & & & \multirow[t]{2}{*}{$\mathrm{x}$} & $\mathrm{x}$ \\
\hline & & & & $\mathrm{X}$ \\
\hline & \multirow{6}{*}{$\mathrm{r}^{\mathrm{B}} \mathrm{v}^{\mathrm{H} * *}$} & \multirow{4}{*}{$\mathbf{r}^{\mathrm{B}} \mathbf{K} \mathbf{n}^{\mathrm{B}}$} & \multirow[t]{2}{*}{$r^{\mathrm{B}} K \Pi^{\mathrm{B}} К щ^{\mathrm{B} * *}$} & $\mathrm{x}$ \\
\hline & & & & $\mathrm{x}$ \\
\hline & & & \multirow[t]{2}{*}{$\mathrm{r}^{\mathrm{B}} \mathrm{K} \Pi^{\mathrm{B}} \mathrm{K} \Psi^{\mathrm{H} * *}$} & $\mathrm{x}$ \\
\hline & & & & $\mathrm{x}$ \\
\hline & & & \multirow[t]{2}{*}{$r^{\mathrm{B}} \mathrm{K} \Pi^{\mathrm{H}} \mathrm{K} щ^{\mathrm{B} * *}$} & $\mathrm{x}$ \\
\hline & & & & $\mathrm{x}$ \\
\hline
\end{tabular}




\begin{tabular}{|c|c|c|c|c|}
\hline & & \multirow[t]{2}{*}{$\mathbf{r}^{\mathrm{B}} \mathbf{K}_{\boldsymbol{I}^{\mathrm{H}}}$} & \multirow[t]{2}{*}{$\mathrm{r}^{\mathrm{B}} \mathrm{K} \Pi^{\mathrm{H}} \mathrm{K} щ^{\mathrm{H}} * *$} & $\mathrm{x}$ \\
\hline & & & & $\mathrm{x}$ \\
\hline \multirow[t]{16}{*}{$\mathrm{r}^{\mathrm{H}}$} & \multirow[t]{8}{*}{$\mathrm{r}^{\mathrm{H}} \mathrm{v}^{\mathrm{B}}$} & \multirow[t]{4}{*}{$r^{\mathrm{H}} v^{\mathrm{B}} K \Pi^{\mathrm{B}} * *$} & \multirow[t]{2}{*}{$\mathrm{x}$} & $\mathrm{x}$ \\
\hline & & & & $\mathrm{x}$ \\
\hline & & & \multirow[t]{2}{*}{$\mathrm{x}$} & $\mathrm{x}$ \\
\hline & & & & $\mathrm{x}$ \\
\hline & & \multirow[t]{4}{*}{$r^{\mathrm{H}} v^{\mathrm{B}} K_{\Pi^{\mathrm{H}}}$} & \multirow{2}{*}{$\mathrm{r}^{\mathrm{H}} v^{\mathrm{B}} \mathrm{K}^{\mathrm{H}} \mathrm{K}^{\mathrm{B}}{ }^{\mathrm{B}}$} & $r^{\mathrm{H}} v^{\mathrm{B}} \mathrm{K}^{\mathrm{H}}{ }^{\mathrm{H}}{ }^{\mathrm{B}}{ }^{\mathrm{B}} \mathrm{Ka}^{\mathrm{B}}$ \\
\hline & & & & $r^{\mathrm{H}} v^{\mathrm{B}} K_{\pi^{\mathrm{H}}}{ }^{\prime} щ^{\mathrm{B}}{ }^{3} a^{\mathrm{H}}$ \\
\hline & & & \multirow[t]{2}{*}{$\mathrm{r}^{\mathrm{H}} v^{\mathrm{B}} \mathrm{K}^{\mathrm{H}}{ }^{\mathrm{H}} \mathrm{K} \Psi^{\mathrm{H}}$} & $\mathrm{r}^{\mathrm{H}} \mathrm{v}^{\mathrm{B}} \mathrm{K}_{\pi^{\mathrm{H}}}^{\mathrm{H}} \mathrm{K}^{\mathrm{H}}{ }^{\mathrm{H}} \mathrm{Ka}^{\mathrm{B}}$ \\
\hline & & & & $\mathrm{r}^{\mathrm{H}} \mathrm{v}^{\mathrm{B}} \mathrm{K}_{\pi^{\mathrm{H}}}^{\mathrm{H}}{ }^{\mathrm{H}}{ }^{\mathrm{H}} \mathrm{Ka}^{\mathrm{H}}$ \\
\hline & \multirow[t]{8}{*}{$\mathrm{r}^{\mathrm{H}} \mathrm{v}^{\mathrm{H}}$} & \multirow[t]{4}{*}{$r^{\mathrm{H}} v^{\mathrm{H}} K \Pi^{\mathrm{B}} * *$} & \multirow[t]{2}{*}{$\mathrm{x}$} & $\mathrm{x}$ \\
\hline & & & & $\mathrm{x}$ \\
\hline & & & \multirow[t]{2}{*}{$\mathrm{x}$} & $\mathrm{x}$ \\
\hline & & & & $\mathrm{x}$ \\
\hline & & \multirow[t]{4}{*}{$\mathrm{R}^{\mathrm{H}} \mathrm{v}^{\mathrm{H}} \mathrm{K} \Pi^{\mathrm{H}}$} & \multirow[t]{2}{*}{$\mathrm{r}^{\mathrm{H}} v^{\mathrm{H}} \mathrm{K} \Pi^{\mathrm{H}} \mathrm{K}^{\mathrm{B}}{ }^{\mathrm{B}}$} & $r^{\mathrm{H}} v^{\mathrm{H}} K{ }^{\mathrm{H}} K u^{\mathrm{B}} K a^{\mathrm{B}}$ \\
\hline & & & & $r^{\mathrm{H}} v^{\mathrm{H}} K \Pi^{\mathrm{H}} K w^{\mathrm{B}} \mathrm{Ka}^{\mathrm{H}}$ \\
\hline & & & \multirow[t]{2}{*}{$r^{\mathrm{H}} v^{\mathrm{H}} K \Pi^{\mathrm{H}} K щ^{\mathrm{H}}$} & $r^{\mathrm{H}} v^{\mathrm{H}} K \Pi^{\mathrm{H}} K w^{\mathrm{H}} \mathrm{Ka}^{\mathrm{B}}$ \\
\hline & & & & $r^{\mathrm{H}} v^{\mathrm{H}} K n^{\mathrm{H}} K{ }^{\mathrm{H}}{ }^{\mathrm{H}} a^{\mathrm{H}}$ \\
\hline
\end{tabular}

відповідно.

* позначки ${ }^{\text {в, н }}$ при коефіцієнтах означають їх високий та низький рівень,

**позначаються малоймовірні варіанти конфігурації

Отримані реалістичні варіанти потребують аналітичної інтерпретації та визначення типу нестабільності досліджуваного показника (табл. 3).

Узагальнена характеристика нестабільності зовнішнього організаційного середовища формується на основі переважної якісної ознаки по більшості досліджуваних показниках - прогнозованості змін $\left(\mathrm{r}^{\mathrm{B}}, \mathrm{r}^{\mathrm{H}}\right)$, а також конфігурацій додаткових показників нестабільності - коефіцієнтів варіації, пікових відхилень, аритмії, які слугує аналітичною основою визначення можливих змін у характері даного середовища.

Таблиця 3

Аналітична інтерпретації конфігурацій коефіцієнтів нестабільності досліджуваного показника зовнішнього середовища підприємства та визначення його якісної ознаки

\begin{tabular}{|c|c|c|}
\hline $\begin{array}{c}\text { Варіанти } \\
\text { конфігурацій }\end{array}$ & Виявлені аналітичні ознаки нестабільності & $\begin{array}{c}\text { Пріоритетна } \\
\text { ознака } \\
\text { нестабільності }\end{array}$ \\
\hline $\mathrm{r}^{\mathrm{B}} \mathrm{K} \Pi^{\mathrm{B}}$ & Тенденція з прискоренням & турбулентніст \\
\hline $\mathrm{r}^{\mathrm{B}} \mathrm{K}^{\mathrm{H}}$ & $\begin{array}{l}\text { Стабільна тенденції, відсутність значущих } \\
\text { відхилень та аритмії змін }\end{array}$ & динамічність \\
\hline$r^{\mathrm{H}} v^{\mathrm{B}} \mathrm{K} \Pi^{\mathrm{H}} \mathrm{K} щ^{\mathrm{B}} \mathrm{Ka}^{\mathrm{B}}$ & $\begin{array}{l}\text { Відсутність тенденції за високої варіації, щільності і } \\
\text { аритмії змін }\end{array}$ & стохастичність \\
\hline $\mathrm{r}^{\mathrm{H}} \mathrm{v}^{\mathrm{B}} \mathrm{K}^{\mathrm{H}}{ }^{\mathrm{K}}{ }^{\mathrm{B}} \mathrm{Ka}^{\mathrm{H}}$ & $\begin{array}{l}\text { Відсутність тенденції за високої варіації і щільності } \\
\text { пікових відхилень при незначній аритмії змін }\end{array}$ & стохас \\
\hline $\mathrm{r}^{\mathrm{H}} \mathrm{v}^{\mathrm{B}} \mathrm{K} \Pi^{\mathrm{H}} \mathrm{K}^{\mathrm{H}}{ }^{\mathrm{H}} \mathrm{Ka}^{\mathrm{B}}$ & $\begin{array}{l}\text { Відсутність тенденції за високої варіації і аритмії змін } \\
\text { при незначних пікових відхиленнях }\end{array}$ & стохастичність \\
\hline $\mathrm{r}^{\mathrm{H}} \mathrm{v}^{\mathrm{B}} \mathrm{K} \Pi^{\mathrm{H}} \mathrm{K} \omega^{\mathrm{H}} \mathrm{Ka}^{\mathrm{H}}$ & $\begin{array}{l}\text { Відсутність тенденції за високої варіації і незначних } \\
\text { пікових відхиленнях при незначній аритмії змін }\end{array}$ & $\begin{array}{l}\text { стохастична } \\
\text { стагнація }\end{array}$ \\
\hline $\mathrm{r}^{\mathrm{H}} \mathrm{v}^{\mathrm{H}} \mathrm{K} n^{\mathrm{H}} \mathrm{K} щ^{\mathrm{B}} \mathrm{Ka}^{\mathrm{B}}$ & $\begin{array}{l}\text { Відсутність тенденції за низької варіації і високої } \\
\text { щільності і аритмії змін }\end{array}$ & стохастичність \\
\hline $\mathrm{r}^{\mathrm{H}} \mathrm{v}^{\mathrm{H}} \mathrm{K} \Pi^{\mathrm{H}} \mathrm{K} \mu^{\mathrm{B}} \mathrm{Ka}^{\mathrm{H}}$ & Відсутність тенденції за низької динамічної варіації і & стохастична \\
\hline
\end{tabular}




\begin{tabular}{|l|l|c|}
\hline & $\begin{array}{l}\text { високої щільності пікових відхилень при незначній } \\
\text { аритмії змін }\end{array}$ & стагнація \\
\hline $\mathrm{r}^{\mathrm{H}} \mathrm{v}^{\mathrm{H}} \mathrm{K}^{\mathrm{H}} \mathrm{Kщ}^{\mathrm{H}} \mathrm{Ka}^{\mathrm{B}}$ & $\begin{array}{l}\text { Відсутність тенденції за низької варіації і високої аритмії } \\
\text { змін при незначних пікових відхиленнях }\end{array}$ & $\begin{array}{l}\text { стохастична } \\
\text { стагнація }\end{array}$ \\
\hline $\mathrm{r}^{\mathrm{H}} \mathrm{v}^{\mathrm{H}} \mathrm{K}^{\mathrm{H}} \mathrm{K}^{\mathrm{H}} \mathrm{Ka}^{\mathrm{H}}$ & $\begin{array}{l}\text { Відсутність тенденції за низьких значень варіації, пікових } \\
\text { відхиленнях і аритмії змін }\end{array}$ & стагнація \\
\hline
\end{tabular}

Так, у варіанті $\mathrm{r}^{\mathrm{H}} \mathrm{v}^{\mathrm{B}} \mathrm{K} \Pi^{\mathrm{H}} \mathrm{K}{ }^{\mathrm{B}} \mathrm{Ka}^{\mathrm{H}}-$ характер середовища визначено як стохастичний, а невисока аритмія змін показника $\epsilon$ свідчення закріплення існуючого статусу і низької ймовірності його перегляду.

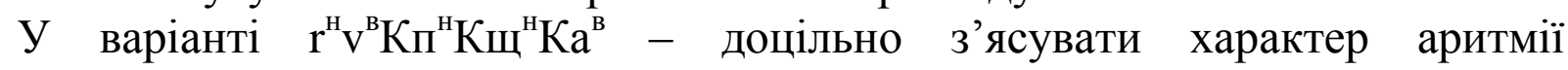
досліджуваного показника за періодами спостереження. В разі зменшення варіації змін в останньому періоді, тим більше за наявного низького рівня пікових відхилень, можна прогнозувати зменшення стохастичності показника у майбутньому.

Отже, з’ясування рівня нестабільності середовища слугує передумовою визначенню його прогнозних характеристик, що трансформується в рівень передбачуваності змін зовнішнього середовища. Змістовною основою даного припущення $\epsilon$ коректність використання минулого досвіду $\mathrm{i}$ набутих управлінських навичок у перспективі, а у деяких випадках - доречність екстраполяції існуючих тенденцій.

Оцінювання нестабільності зовнішнього середовища потребує вибору об'єктів оцінки - показників розвитку середовища. Динаміка зазначених показників має відображати характер нестабільності середовища, який можна виявити лише на основі оцінки контрольованих наслідків зовнішніх змін. Це єдиний критерій, за яким оцінка середовища буде мати реальний характер, що підтверджується параметрами значимого впливу.

Вибір показників - об’єктів оцінки рівня нестабільності середовища, має грунтуватись на певних вимогах, дотримання яких забезпечить об'єктивність $\mathrm{i}$ комплексність зазначеної оцінки на основі кількісно визначених характеристик.

До основних таких вимог слід віднести:

- системність відбору показників, яка дозволить дати оцінку нестабільності з різних позицій їі прояву і сфер реалізації;

- зосередженість на основних характеристиках середовища, що інтегрують вплив певних груп зовнішніх чинників;

- якомога більша обопільна незалежність даних показників, що забезпечить оцінювання результативності впливу різних за характером чинників зовнішнього середовища;

- придатність визначених показників для оцінювання нестабільності в різних галузях економіки;

- кількісна вимірність їхніх параметрів в придатних до порівняльного аналізу одиницях.

Вимога системності відбору показників реалізується на основі врахування функціонального призначення сфер діяльності підприємства, які формуються під 
впливом взаємозалежних зовнішніх чинників певного спрямування, а саме, виробничих, маркетингових, фінансово-економічних i організаційних. Тому, об'єктами оцінки мають бути відповідні сегменти середовища та показники, що характеризують їхню динаміку (табл. 4).

Сегмент виробничої діяльності акумулює результативність впливу зовнішніх чинників на обсяг і структуру виробництва. Дослідження динаміки відповідних показників дозволить з'ясувати рівень виробничої нестабільності середовища, яка $є$ первинною по відношенню до маркетингової, фінансовоекономічної і організаційної.

Маркетингову діяльність спрямовано на отримання визнання доцільності виробництва продукції споживачами. Основними показниками, що характеризують масштабність цього процесу є обсяг реалізованої продукції в цілому i по окремих, найбільш аналітично значимих іiі видах. Крім того, важливою ознакою маркетингової діяльності є ціна реалізації даної продукції. Вона залежить не стільки від їі калькулювання виробниками, скільки від зовнішніх умов реалізації. Це обумовлює ii вагоме значення як показника нестабільності організаційного середовища.

Поєднання маркетингових і виробничих чинників середовища реалізується у фінансово - економічних показниках, головними 3 яких $\epsilon$ рентабельність реалізації продукції.

Дослідження організаційного середовища функціонування виноробних підприємств має особливу актуальність. Висока потенційна рентабельність виноробства і відносно низька капіталоємність приваблює велику кількість інвесторів. Результатом цього є значна чисельність підприємств, які визначили для себе виноробство як пріоритетний вид діяльності. Проте необхідність володіння спеціальними компетенціями, зокрема, технологічними, обумовлює складнощі діяльності новостворених підприємств. В результаті значна їхня частина не витримує конкуренції і припиняє діяльність, інші - виживають за незначних обсягах виробництва, або намагаються впроваджувати спрощені технології, іноді - фальсифікувати продукцію. Зазначене додає динамізму зовнішньому організаційному середовищу, а оцінка рівня його нестабільності за показниками кількості зареєстрованих $\mathrm{i}$ діючих виноробних підприємств $\epsilon$ виправданим аналітичним рішенням.

Таблиця 4

Об’єкти оцінювання рівня нестабільності зовнішнього середовища виноробних підприємств України

\begin{tabular}{|c|c|c|c|}
\hline \multicolumn{3}{|c|}{ Об’єкти оцінки } & \multirow{3}{*}{$\begin{array}{l}\text { Одиниці } \\
\text { виміру }\end{array}$} \\
\hline \multirow{2}{*}{$\begin{array}{c}\text { Функціональні } \\
\text { сегменти } \\
\text { середовища }\end{array}$} & \multicolumn{2}{|r|}{ Показники } & \\
\hline & Основні & Додаткові & \\
\hline \multirow[t]{2}{*}{$\begin{array}{l}\text { Виробнича } \\
\text { діяльність }\end{array}$} & $\begin{array}{l}\text { Обсяг } \\
\text { виробництва }\end{array}$ & $\begin{array}{l}\text { Обсяги виробництва по основних } \\
\text { асортиментних позиціях }\end{array}$ & мЛн. дал \\
\hline & $\begin{array}{l}\text { Частка основної } \\
\text { асортиментної } \\
\text { позиції }\end{array}$ & $\begin{array}{l}\text { Частки найменувань продукції по } \\
\text { асортиментних позиціях }\end{array}$ & $\%$ \\
\hline Маркетингова & Обсяг & реалізації & млн. грн. \\
\hline
\end{tabular}




\begin{tabular}{|c|c|c|c|}
\hline \multirow[t]{3}{*}{ діяльність } & реалізації & асортиментних позиціях & \multirow[b]{2}{*}{$\%$} \\
\hline & $\begin{array}{l}\text { Частка основної } \\
\text { асортиментної } \\
\text { позиції }\end{array}$ & $\begin{array}{l}\text { Частки найменувань реалізованої } \\
\text { продукції по по асортиментних } \\
\text { позиціях }\end{array}$ & \\
\hline & $\begin{array}{l}\text { Ціна одиниці } \\
\text { реалізації }\end{array}$ & $\begin{array}{l}\text { Ціна одиниці } \quad \text { реалізації } \\
\text { асортиментних позиціях }\end{array}$ & грн. \\
\hline $\begin{array}{l}\text { Фінансово- } \\
\text { економічна } \\
\text { діяльність }\end{array}$ & $\begin{array}{l}\text { Рентабельність } \\
\text { реалізації }\end{array}$ & $\begin{array}{l}\text { Рентабельність реалізації } \\
\text { асортиментних позиціях }\end{array}$ & $\%$ \\
\hline $\begin{array}{l}\text { Організаційна } \\
\text { діяльність }\end{array}$ & $\begin{array}{l}\text { Кількість } \\
\text { зареєстрованих } \\
\text { підприємств } \\
\end{array}$ & $\begin{array}{l}\text { Кількість } \\
\text { підприємств зареєстрованих } \\
\text { обсягом діяльності, спеціалізацією }\end{array}$ & одиниць \\
\hline & $\begin{array}{l}\text { Кількість } \\
\text { діючих } \\
\text { підприємств }\end{array}$ & $\begin{array}{lcr}\text { Кількість діючих підприємств } & \text { за } \\
\text { формою } & \text { власності, } & \text { обсягом } \\
\text { діяльності, спеціалізацією } & \end{array}$ & одиниць \\
\hline & $\begin{array}{l}\text { Частка діючих } \\
\text { підприємств }\end{array}$ & $\begin{array}{lcr}\text { Частки } & \text { діючих підприємств за } \\
\text { формою } & \text { власності, } & \text { обсягом } \\
\text { діяльності, спеціалізацією } & \end{array}$ & $\%$ \\
\hline
\end{tabular}

Призначенням додаткових показників є забезпечення більшої деталізації характеристик нестабільності. Особливо це буде у нагоді в разі отримання неоднозначних висновків за результатами розрахунку коефіцієнтів нестабільності основних показників. Крім того, в процесі аналізу середовища може виникнути потреба у додатковому дослідженні характеру його нестабільності в окремих сегментах, де індикаторами слугуватимуть дані показники.

Прикладне застосування визначених основних показників - об'єктів оцінювання нестабільності середовища функціонування виноробних підприємств України обумовило необхідність внесення корективів у їхній перелік.

При визначенні нестабільності маркетингового середовища за об'єкт розрахунку було взято обсяг реалізації вина, що пов'язано 3 необхідністю забезпечення кореспонденції даного показника 3 ціною одиниці продукції, параметри якої є доступними. Крім того, середня ціна, визначена у гривнях за один декалітр по усіх видах виноробної продукції, має високий рівень агрегації, який залежить від структурних ознак усього обсягу виробництва. Оцінка рівня нестабільності середовища на основі даного показника може нівелювати дію декількох чинників, значення яких має аналітичну важливість.

Проведені розрахунки досліджуваних показників нестабільності середовища функціонування виноробних підприємств України засвідчили значну диференціацію іiі рівнів (табл.5)

Таблиця 5

Результати оцінювання рівня прогнозованості показників зовнішнього середовища виноробних підприємств України за функціональними сегментами за $2007-2013$ pp.

\begin{tabular}{|c|c|c|c|c|c|}
\hline Об’єкти оцінки & \multicolumn{2}{|c|}{ Параметри оцінки } & \multirow{2}{*}{$\begin{array}{c}\text { Рівень } \\
\text { прогнозо- }\end{array}$} & \multicolumn{2}{|c|}{$\begin{array}{c}\text { Якісні ознаки } \\
\text { динаміки }\end{array}$} \\
\hline Функціональні & Лінія тренду & Коеф. & & при- & упо- \\
\hline
\end{tabular}




\begin{tabular}{|c|c|c|c|c|c|c|}
\hline $\begin{array}{l}\text { сегменти } \\
\text { середовища }\end{array}$ & Показники & & $\begin{array}{c}\text { детерм., } \\
\mathrm{R}^{2}\end{array}$ & ваності & $\begin{array}{l}\text { ско- } \\
\text { рення }\end{array}$ & $\begin{array}{c}\text { віль- } \\
\text { нення }\end{array}$ \\
\hline \multirow{2}{*}{$\begin{array}{l}\text { Виробнича } \\
\text { діяльність }\end{array}$} & $\begin{array}{l}\text { Виробництво } \\
\text { винопродукції }\end{array}$ & $y=34,296 e^{-0,01 x}$ & 0,0231 & $\begin{array}{l}\text { непрогнозо- } \\
\text { ваний }\end{array}$ & - & - \\
\hline & $\begin{array}{l}\text { Частка вина } \\
\text { натурального }\end{array}$ & $y=62,992 e^{0,029 x}$ & 0,5027 & $\begin{array}{l}\text { непрогнозо- } \\
\text { ваний }\end{array}$ & - & - \\
\hline \multirow[t]{2}{*}{$\begin{array}{l}\text { Маркетингова } \\
\text { діяльність }\end{array}$} & $\begin{array}{l}\text { Реалізації вина } \\
\text { натурального } \\
\text { вітчизняними } \\
\text { виробниками }\end{array}$ & $y=2554,6 x^{0,3019}$ & 0,2699 & $\begin{array}{l}\text { непрогнозо- } \\
\text { ваний }\end{array}$ & - & - \\
\hline & $\begin{array}{l}\text { Ціна одиниці } \\
\text { реалізації }\end{array}$ & $\mathrm{y}=130,81 \mathrm{x}^{0,3678}$ & 0,8263 & $\begin{array}{l}\text { прогнозова- } \\
\text { аний }\end{array}$ & - & так \\
\hline $\begin{array}{l}\text { Фінансово- } \\
\text { економічна } \\
\text { діяльність }\end{array}$ & $\begin{array}{l}\text { Рентабельність } \\
\text { реалізації }\end{array}$ & $\begin{array}{l}y=-1,016 \ln (x)+ \\
1,8984\end{array}$ & 0,0370 & $\begin{array}{l}\text { непрогнозо- } \\
\text { ваний }\end{array}$ & - & - \\
\hline \multirow[t]{3}{*}{$\begin{array}{l}\text { Організаційна } \\
\text { діяльність }\end{array}$} & $\begin{array}{l}\text { Кількість } \\
\text { зареєстрованих } \\
\text { підприємств }\end{array}$ & $y=305,34 x^{0,1527}$ & 0,7375 & $\begin{array}{l}\text { прогнозова- } \\
\text { ний }\end{array}$ & - & так \\
\hline & $\begin{array}{l}\text { Кількість } \\
\text { діючих } \\
\text { підприємств }\end{array}$ & $y=334,23 e^{-0,1044 x}$ & 0,6371 & $\begin{array}{l}\text { непрогнозо- } \\
\text { ваний }\end{array}$ & - & - \\
\hline & $\begin{array}{l}\text { Частка діючих } \\
\text { підприємств }\end{array}$ & $\begin{array}{l}y=-9,4571 x+ \\
99,567\end{array}$ & 0,9321 & $\begin{array}{l}\text { прогнозова- } \\
\text { ний }\end{array}$ & - & так \\
\hline
\end{tabular}

38 досліджених показників 5 виявились не прогнозованими, що є ознакою стохастичності змін середовища. Разом з цим, прогнозованість 3 інших не слід вважити безальтернативно значимою ознакою прогнозованості змін у виноробстві України. Так, наявність тенденції динаміки кількості зареєстрованих підприємств здебільшого обумовлено прогресуючим збільшенням кількості зареєстрованих підприємств, значна частина яких не стають діючими. Підтвердженням цьому є недостатній рівень прогнозованості показника діючих підприємств - коефіцієнт детермінації - 0,6371 не відповідає визначеному критерію 0,7. Тому наявність тенденціє збільшення кількості зареєстрованих підприємств (за не прогнозованості діючих) є свідченням нестабільності середовища, суб'єкти якого ще остаточно не визначились 3 доцільністю (або можливістю) розпочати реальну господарську діяльність на виноробному ринку, але зареєстрували підприємства 3 надією на стабілізацію галузевих умов.

При цьому частка діючих підприємств має окреслену тенденцію до зниження з уповільненим характером, що $є$ передумовою стабілізації кількості учасників досліджуваного ринку.

Динаміка показників, яку визнано не прогнозованою, потребує подальшого дослідження і оцінювання (табл. 6).

Таблиця 6

Результати оцінювання рівня нестабільності зовнішнього середовища виноробних підприємств України за не прогнозованими показниками за $2007-2013$ pp.

\begin{tabular}{l|l|l|l} 
Об’єкти & Коефіцієнти нестабільності & Конфігурація & Рівень
\end{tabular}




\begin{tabular}{|c|c|c|c|c|c|}
\hline оцінки & $\begin{array}{l}\text { Варіації, } \\
\text { (Кв) }\end{array}$ & $\begin{array}{c}\text { Щільності } \\
\text { пікових } \\
\text { змін, } \\
\text { (Кщ) }\end{array}$ & $\begin{array}{c}\text { Аритмії } \\
\text { змін, (Ка) }\end{array}$ & $\begin{array}{l}\text { значень } \\
\text { коефіцієнтів } \\
\text { нестабільності }\end{array}$ & $\begin{array}{l}\text { нестабільності, В } \\
\text { - високий, } \\
\text { С - середній, } \\
\text { Н - низький }\end{array}$ \\
\hline $\begin{array}{l}\text { Виробництво } \\
\text { винопродукції }\end{array}$ & 0,487 & 0,204 & 0,451 & $\mathrm{~K}_{\mathrm{B}}{ }^{\mathrm{B}} \mathrm{K}^{\mathrm{H}} \mathrm{Ka}^{\mathrm{B}}$ & $\mathrm{C}$ \\
\hline $\begin{array}{l}\text { Частка вина } \\
\text { натурального }\end{array}$ & 0,351 & 0,264 & 0,325 & $\mathrm{~K}^{\mathrm{B}}{ }^{\mathrm{K}} щ^{\mathrm{B}} \mathrm{Ka}^{\mathrm{B}}$ & $\mathrm{B}$ \\
\hline $\begin{array}{l}\text { Реалізації вина } \\
\text { натурального } \\
\text { вітчизняними } \\
\text { виробниками }\end{array}$ & 0,532 & 0,452 & 0,021 & $\mathrm{~KB}^{\mathrm{B}} \mathrm{K}^{\mathrm{B}} \mathrm{Ka}^{\mathrm{H}}$ & $\mathrm{C}$ \\
\hline $\begin{array}{l}\text { Рентабельність } \\
\text { реалізації }\end{array}$ & 0,682 & 0,325 & 0,056 & $\mathrm{~K}^{\mathrm{B}}{ }^{\mathrm{K}} щ^{\mathrm{B}} \mathrm{Ka}^{\mathrm{H}}$ & $\mathrm{C}$ \\
\hline $\begin{array}{l}\text { Частка діючих } \\
\text { підприємств }\end{array}$ & 0,385 & 0,122 & 0,301 & $\mathrm{~K}^{\mathrm{B}}{ }^{\mathrm{K}} щ^{\mathrm{H}} \mathrm{Ka}^{\mathrm{H}}$ & $\mathrm{C}$ \\
\hline
\end{tabular}

Розрахунки коефіцієнтів нестабільності досліджуваного середовища засвідчила високий та середній рівень нестабільності за не прогнозованими показниками. Причому розмах варіації параметрів коефіцієнтів нестабільності досягав великих значень: 0,331 (0,682 -0,351) за коефіцієнтом варіації і 0,430 (0,451 - 0,021) за коефіцієнтом аритмії.

Низький рівень міг би бути ідентифікований за наявності трьох низьких значень коефіцієнтів варіації, щільності пікових змін і аритмії. Але зазначений висновок був би результатом помилкових розрахунків, або не обгрунтовано визначених оціночних коефіцієнтів, оскільки не прогнозованість наведених показників навряд чи спостерігалась би за умов низької нестабільності середовища.

Для кожного сегменту середовища характерні свої особливості динаміки досліджуваних показників, зокрема, потребує з'ясування проблема суперечливості характеристик нестабільності в сегменті маркетингової діяльності - яким чином підтримується прогнозованість середньої ціни реалізації вина при відсутності будь-якої тенденції в обсязі реалізації вина; звертає на себе увагу помітна аритмія змін значень показників обсягу виробництва усієї продукції виноробства і частки вина натурального. Це означає, що інтенсивність змін за окремими періодами $\epsilon$ різною, a, отже, i прогнозованість даних показників за різними ретроспективними відрізками часу може мати диференційований характер. Візуальне спостереження за динамікою названих показників, а у подальшому i відповідні розрахунки, підтвердили дане припущення (табл. 7).

Таблиця 7

Результати порівняльного оцінювання рівня прогнозованості показників зовнішнього середовища виноробних підприємств України за $2007-2013$ i $2010-2013$ pp.

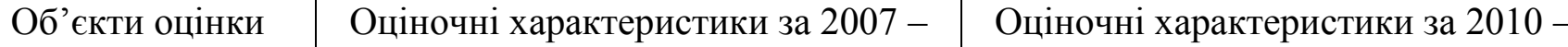
2013 pp. 2013 pp. 


\begin{tabular}{|l|c|c|c|c|}
\hline & Лінія тренду & Коеф. детерм., $\mathrm{R}^{2}$ & Лінія тренду & Коеф. детерм., $\mathrm{R}^{2}$ \\
\hline $\begin{array}{l}\text { Виробництво } \\
\text { винопродукції }\end{array}$ & $\mathrm{y}=34,296 \mathrm{e}^{-0,01 \mathrm{x}}$ & 0,0231 & $\mathrm{y}=44,39 \mathrm{x}^{-0,421}$ & 0,9838 \\
\hline $\begin{array}{l}\text { Частка вина } \\
\text { натурального }\end{array}$ & $\mathrm{y}=62,992 \mathrm{e}^{-0,029 \mathrm{x}}$ & 0,5027 & $\mathrm{y}=61,065 \mathrm{x}^{-0,234}$ & 0,9838 \\
\hline
\end{tabular}

Так, за відсутності прогнозованості показників обсягу виробництва вино продукції і частки вина натурального за 2007 - 2013 рр. (значення коефіцієнту детермінації за цими показниками були меншими за допустимі - 0,0231 і 0,5027, відповідно), відхилення теоретичних значень лінії тренду від фактичних за 2010 - 2013 рр., були мінімальними $\left(\mathrm{R}^{2}=0,9838\right.$ і 0,9838). Це свідчить про можливість прогнозування даних показників з високим рівнем довіри, а, отже, і про високу їхню динамічну стабільність.

Висновок. Оцінювання нестабільності зовнішнього організаційного середовища має здійснюватись на базі науково обгрунтованих критеріїв та системи відповідних показників.

Основними критеріями, як мірила рівня нестабільності середовища, можуть слугувати: наявність тенденції у зміні досліджуваних показників; визначений рівень варіативності змін; спонтанність потужних змін; періодична диференціації варіативності виявлених змін.

На основі даних критеріїв та запропонованої системи показників коефіцієнтів часової кореляції за визначеним трендом, варіації у часі, прискорення, щільності пікових відхилень та аритмії змін; - формується уявлення про відповідний тип зовнішнього організаційного середовища: динамічне, турбулентне, стагнаційне, стохастичне.

Відбір показників - об'єктів оцінки нестабільності середовища, доцільно здійснювати 3 урахуванням функціонального призначення сфер діяльності підприємства, а саме, виробничої, маркетингової, фінансово-економічної і організаційної.

Комплексна оцінка рівня нестабільності середовища передбачає використання методу матричного позиціонування, який дозволяє отримувати системні аналітичні висновки, необхідні для прийняття відповідних управлінських рішень.

Здійснені розрахунки нестабільності зовнішнього середовища виноробних підприємств України дозволяє зробити наступні узагальнення:

- для переважної більшості досліджених показників характерна стохастична нестабільність, що унеможливлює прогнозування їхніх параметрів;

- найвища нестабільність характерна для сегментів виробничої i фінансово-економічної діяльності виноробної галузі; 
- для не прогнозованих показників характерні середній та високий рівень нестабільності, що визначається розрахованими коефіцієнтами варіації, щільності пікових змін і аритмї;

- вагоме значення має сегментна оцінка нестабільності в середовищі виноробних підприємств, що слугує передумовою передбачення майбутніх змін в окремих сферах діяльності, необхідного при реалізації завдань стратегічного управління.

\section{Література:}

1. Ансофф И. Стратегическое управление. / И. Ансофф, [пер. с англ.]. - М.: Экономика, 1989. - 519 c.

2. Васюткін Н.В. Вплив зовнішнього сереловища на складові системи управління розвитком підприємств авіаційної галузі / Н.В. Васюткін // Бизнес Информ.- 2014. - № 5. С. 384-389.

3. Кіпа Д.В. Визначення впливу зовнішнього середовища на формування конкурентної стратегії підприємства / Д.В. Кіпа // Бизнес Информ. - 2014. - № 9, С. 189 - 193.

4. Копосов Г.О., Шелухін П.Г. Управління підприємством в умовах невизначеності на основі розробки системи гештальтів (образів) / О.Г. Копосов, П.Г. Шелухін // Бизнес Информ. - 2012. - № 2, С. 195 - 198.

5. Мазаракі А.А. Торговельне підприємство: стратегія, політика, конкурентоспроможність: монографія / А.А. Мазаракі, Д.М. Пшеслінський, І.В.Смолін.- К.: Київ. Нац.. торг.-екон. ун-т, 2010. - 384 с.

6. Момот В.С. Чинники ринкової невизначеності у поведінці підприємств / В.С. Момот. - Дніпропетровськ: ДУЕТ, 2002. - 228 с.

7.Dunkan R. What Is The Right Organization Structura?/ R. Dunkan // Organizational Dynamic's. - Winter, 1979.

8. Emery F.E., Trist E.L. The casual texture of organizational environment / F.E. Emery, E.L Trist. // Human relations. - 1965. - Vol. 18.

9. Emery F.E., Trist E.L. Toward a social ecology / F.E. Emery, E.L Trist - NY, 1973. 